\title{
Fraudulent Reporting Practices by Satyam
}

\author{
Madan Lal Bhasin \\ University Utara Malaysia \\ School of Accountancy, College of Business, Professor, Kedah Darul Aman, Malaysia
}

\begin{abstract}
Fraudulent financial reporting practices can have significant consequences for organizations and all stakeholders, as well as, for public confidence in the capital and security markets. In fact, comprehensive, accurate and reliable financial reporting is the bedrock upon which our markets are based. Keen to project a rosy picture of the Satyam to investors, employees and analysts, Mr. Raju (CEO and Chairman) fudged the account books so that it appeared to be a far bigger enterprise, with high profits and fast growth rate, than it actually was. The Satyam fraud has shattered the dreams of different categories of investors, shocked the government and regulators alike, and led to questioning of the accounting practices of statutory auditors and corporate governance norms in India. This is an exploratory study based on secondary sources of information. An attempt has been made to provide an explanation for various intriguing questions about Satyam scam. After thorough investigations by the $\mathrm{CBI}$ and $\mathrm{SEBI}$, they have unveiled the methodology by which Satyam fraud was engineered. Finally, we recommend "Fraudulent reporting practices should be considered as a serious crime, and accounting bodies, courts and other regulatory authorities in India need to adopt very strict punitive measures to stop such unethical practices".
\end{abstract}

Keywords: Fraudulent financial reporting practices; Satyam computer; modus-operandi; financial statements; corporate governance; auditors; forensic accounting; corporate culture and ethics; SEBI; SFIO; CID; India.

UDC 364.22:631

JEL Classification: I3, Q12, R2

DOI: http://dx.doi.org/10.22178/pos.15-4

\section{Introduction}

Fraudulent financial reporting practices and accounting frauds have occurred in all eras, in all countries, and affected many organizations, regardless of their size, location, or industry. In nutshell, fraudulent financial reporting is a deliberate misstatement in the financial statements (FS). It can include the deliberate falsification of underlying accounting records, intentionally breaching an accounting standard, or knowingly omitting transactions, or required disclosures in the FS. For example, deliberately not disclosing a contingent liability, or significant going concern problems in the notes to the financial statements means that the disclosures required have intentionally not been made. This is an example of fraudulent financial reporting. Thus, financial reporting fraud - an intentional, material misrepresentation of a company's financial statements remains a serious concern for investors and other capital markets stakeholders. In fact, fraudulent financial reporting practices can take many forms. For instance, it may entail deliberate distortion of corporate records (such as, inven- tory count tags), or falsified transactions (such as, fictitious sales or orders), or misapplication of accounting principles. Company employees at any level may be involved, from top to middle management to lower-level personnel. Undoubtedly, fraudulent financial reporting can have significant consequences for the organization, stakeholder, as well as, for public confidence in the capital market. However, fraud impacts organizations in several areas: financial, operational and psychological. Corporate accounting fraud is not a new thing in this world after the debacle of Enron, which proved to be a stimulus for others to fancy their own Enron in their respective organizations. "With increasing trend in financial crimes across the globe, investors have lost their confidence, the credibility of financial disclosures is questioned, and companies are also facing huge financial losses" [31]. Fortunately, the Sarbanes-Oxley Act of 2002 and SEBI's Listing Clause 49 in India have done much to improve corporate governance and deter frauds.

No doubt, recent cases of fraudulent financial reporting, accounting frauds and the resultant out- 
cry for transparency and honesty in reporting, have given rise to two disparate yet logical outcomes. Recently, reiterated, "First, 'forensic' accounting skills have become crucial in untangling the complicated accounting maneuver's that have obfuscated financial statement frauds. Second, public demand for change and subsequent regulatory action has transformed 'corporate governance' (henceforth, CG) scenario" [15]. In fact, both these trends have the common goal of addressing the investors' concerns about the transparent financial reporting system. The failure of the corporate communication structure has made the financial community realize that there is a great need for 'skilled' professionals that can identify, expose, and prevent 'structural' weaknesses in three key areas: poor CG, flawed internal controls, and fraudulent financial statements. "Forensic accounting skills are becoming increasingly relied upon within a corporate reporting system that emphasizes its accountability and responsibility to stakeholders".

Satyam Computer Services Limited (henceforth, Satyam) was once the crown jewel of Indian IT industry, but brought to the ground by its founders in 2009 as a result of financial crime. The debacle of Satyam raised a debate about the role of CEO in driving an organization to the heights of success, its relation with the board members, and role of CG in shaping the protocols related to working of audit committee (AC). Thus, an indepth case study of Satyam is conducted here to analyze the fraudulent accounting reporting scam from accounting and top-level management perspectives.

\section{Review of Literature}

Several analytical studies, from time to time, have been reported in the global media and majority of these studies were performed in developed, Western countries. Unfortunately, no study has been conducted to (a) examine the modusoperandi of the Satyam, India's largest corporate fraud, and (b) analyze the behavioural aspects of top-level management team in the perpetuation of corporate frauds in the context of a developing economy, like India. However, descriptive paper provided good analysis of the Satyam scandal [36]. It covered the areas of history of Satyam, and also provided an insight into how the $\$ 2.7$ billion scandal evaded regulators, investors, and the board of directors. The author also provided a discussion of who was responsible for the fraud, and explained the scandal's effect in India and the implications for dealing with future obstacles. Finally, the author discussed the regulatory reforms undertaken following Satyam scam and the current status of Indian securities markets. In another research study performed by M. Bhasin [9], "the main objectives were to: (a) identify the prominent companies involved in fraudulent financial reporting practices, and the nature of accounting irregularities they committed; (b) highlighted the Satyam Computer Limited's accounting scandal by portraying the sequence of events, the aftermath of events, the key parties involved, and major follow-up actions undertaken in India; and (c) what lesions can be learned from Satyam scam?" Another descriptive study by K. Pai and T. Tolleson [28] examined the capture of government regulators using the case of Satyam Computer Services Limited, one of India's largest software and services companies, which disclosed a $\$ 1.47$ billion fraud on its balance sheet on January 7, 2009. The authors reviewed the Satyam fraud and PWC's failure to detect Satyam's accounting shenanigans, and also discussed the societal implications associated with a "too big to fail" mentality and the moral hazard of such a mindset. In addition, the paper provides suggestions to protect the public interest while citing lessons learned from this scandal.

Similarly, M. Bhasin [13] performed another research study by applying a questionnaire-based survey among 345 bank employees to know their perception towards bank frauds and evaluate the factors that influence the degree of their compliance level. The study reveals that "there are poor employment practices and lack of effective employee training; usually over-burdened staff, weak internal control systems, and low compliance levels on the part of Bank Managers, Offices and Clerks". However, an exploratory research was conducted by P. Gupta and S. Gupta [21] through a combined mode of structured questionnaires from 346 sample companies and 43 interviews with the corporate professionals, management, investors, government offices and authorities having wide experience. They found that the regulatory system is weak, there is dire need to redefine the role of auditors, coordination among different regulatory authorities is poor, and after every scam, there is a blame game". Recently, M. Bhasin [16] conducted a study using a questionnaire-based survey meth- 
odology, where in 14 specific research questions were asked. In all, 120 questionnaires were distributed to the preparers' and users' of the company FS and 85 responses from the participants were collected and analyzed using the percentage and frequencies of respondents. The study revealed that the practice of creative accounting (CA) is always a deliberate attempt to gain undue advantage for accountants, managers and companies. We recommend that "CA practices should be considered as a serious crime, and as such, accounting bodies, law courts and other regulatory authorities need to adopt very strict punitive measures to stop unethical CA practices".

Accordingly, the primary objective of this paper is to examine managers' unethical behaviours in documented corporate fraud cases, on the basis of press articles, which constitute an ex-post evaluation of alleged or acknowledged fraud cases. Unfortunately, no study has been conducted to examine behavioural aspects of manager's in the perpetuation of corporate frauds in the context of a developing economy, like India. Hence, the present study seeks to fill this gap and contributes to the literature.

\section{Research Methodology}

Financial reporting practice can be developed by reference to a particular setting in which it is embedded. Therefore, 'qualitative' research could be seen useful to explore and describe fraudulent financial reporting practice. An attempt has been made by the author to provide a brief description about the modus-operandi used by the top-level management at Satyam, based on reports of various Indian investigative agencies and media reports to commit the accounting fraud, duly supported by documentary evidence. Here, two issues are crucial. First, to understand why and how a 'specific' company is committed to fraudulent financial reporting practice an appropriate "interpretive" research approach is needed. Second, case study conducted as part of this study, looked specifically at the largest fraud case in India, involving Satyam. The Satyam accounting fraud has, for the first time, comprehensively exposed the failure of the regulatory oversight mechanism in India. No doubt, to design better accounting systems, we need to understand how accounting systems operate in their social, political and economic contexts.
Objectives of Study and Sources of Information. To complement prior literature, we examined "documented behaviours in cases of corporate scandals, using the evidence taken from press articles (such as managers' quotes and journalists' analyses)". In terms of information collection 'methodology', we searched for evidence from the U.S. press coverage contained in the "Factiva" database (also called Dow Jones Factiva). It is a non-academic database of international news containing 20,000 worldwide full-text publications including The Financial Times, The Wall Street Journal, as well as the continuous information from Reuters, Dow Jones, and the Associated Press. We also used SEC documents, to understand the technical and accounting aspects of the corporate fraud. For some companies, we also used the restatement reports. Thus, present study is primarily based on "secondary" sources of data, (EBSCO host database), gathered from the related literature published in the journals, newspaper, books, statements, reports. However, as stated earlier, the nature of study is "primarily qualitative, descriptive and analytical". However, no quantitative and statistical tools have been used specifically for analysis of this case study.

\section{Result and Discussion}

Emergence of Satyam. Satyam was a 'rising-star' in the Indian 'outsourced' IT-services industry. The company was formed in 1987 in Hyderabad (India) by Mr. Ramalinga Raju. The firm began with 20 employees, grew rapidly as a 'global' business, which operated in 65 countries around the world. Satyam was the first Indian company to be registered with three International Exchanges (NYSE, DOW Jones and EURONEXT). Satyam was as an example of India's growing success; it won numerous awards for innovation, governance, and corporate accountability [1]. As M. Bhasin [10] commented, "From 2003-2008, in nearly all financial metrics of interest to investors, the company grew measurably, as summarized in Table 1. Satyam generated Rs. 25,415.4 million in total sales in 2003-04. By March 2008, the company sales revenue had grown by over three times. The company demonstrated an annual compound growth rate of $38 \%$ over that period. Similarly, operating profits, net profit and operating cash flows growth averaged 28, 33 and $35 \%$, respectively". Thus, Satyam generated significant corporate growth and shareholder value too. The company was a leading star (and a recognizable name) in a global IT marketplace. 
Table 1 - Operating Performance of Satyam: 2003-04 to 2007-2008, Rs. in millions

\begin{tabular}{|c|c|c|c|c|c|c|}
\hline Particulars & $\begin{array}{l}2003- \\
2004\end{array}$ & $\begin{array}{l}2004- \\
2005\end{array}$ & $\begin{array}{l}2005- \\
2006\end{array}$ & $\begin{array}{l}2006- \\
2007\end{array}$ & $\begin{array}{l}2007- \\
2008\end{array}$ & $\begin{array}{c}\text { Average Growth Rate } \\
(\%)\end{array}$ \\
\hline Net Sales & $25,415.4$ & $34,642.2$ & $46,343.1$ & $62,284.7$ & $81,372.8$ & 38 \\
\hline Operating Profit & 7,743 & 9,717 & $15,714.2$ & $17,107.3$ & $20,857.4$ & 28 \\
\hline Net Profit & $5,557.9$ & $7,502.6$ & $12,397.5$ & $14,232.3$ & $17,157.4$ & 33 \\
\hline Operating Cash Flow & $4,165.5$ & $6,386.6$ & $7,868.1$ & $10,390.6$ & $13,708.7$ & 35 \\
\hline ROCE (\%) & 27.95 & 29.85 & 31.34 & 31.18 & 29.57 & 30 \\
\hline ROE (\%) & 23.57 & 25.88 & 26.85 & 28.14 & 26.12 & 26 \\
\hline
\end{tabular}

Source: www.geogit.com

\section{Ramalinga Raju and Fraudulent Financial Re-} porting Practices at Satyam. Unfortunately, less than five months after winning the Global Peacock Award, Satyam became the center-piece of a 'massive' accounting fraud. Satyam's topmanagement simply cooked the company's books by overstating its revenues, profit margins, and profits for every single quarter over a period of 5-years, from 2003 to 2008. Shockingly, on January 7, 2009, Mr. Raju disclosed in a letter (Figure 1), "He had been manipulating the company's accounting numbers for years. He overstated assets on Satyam's balance sheet by $\$ 1.47$ billion, and nearly $\$ 1.04$ billion in bank loans and cash that the company claimed to own was nonexistent. Satyam also under-reported liabilities on its balance sheet and overstated its income nearly every quarter over the course of several years in order to meet analyst expectations". For example, the results announced on October 17, 2009 overstated quarterly revenues by $75 \%$ and profits by $97 \%$. Mr. Raju and company's global head of internal audit used a number of different techniques to perpetrate the fraud [27].

As S. Ramachandran [30] pointed out, "Using his personal computer, Mr. Raju created numerous bank statements to advance the fraud. He falsified the bank accounts to inflate the balance sheet with balances that did not exist. He also inflated the income statement by claiming interest income from the fake bank accounts. Mr. Raju also revealed that He created 6,000 fake salary accounts over the past few years and appropriated the money after the company deposited it". As M. Bhasin [18] pointed out, "The Satyam's global head of internal audit created fake customer identities and generated fake invoices against their names to inflate revenue. The global head of internal audit also forged board resolutions and illegally obtained loans for the com- pany". It also appeared that the cash that the company raised through American Depository Receipts in the United States never made it to the balance sheets [37].

\section{Satyam's Fraudulent Reporting Methodology}

Unveiled. The unfolding of Satyam sage has been a watershed event in the Indian corporate history. According to the founder's own public confession, Satyam had frequently used fraudulent financial reporting practices by inflating its reported revenues by $25 \%$, its operating margins by over 10 times, and its cash and bank balance by over 1 billion dollars. The magnitude of this scam/fraud makes it by far the biggest accounting scandal in India's history [24]. Now, it is good to see that the Satyam case is different at least in one respect - we now have all the details about the modus operandi of the fraud. Shockingly, how did Raju mastermind this maze of fraudulent accounting practices at Satyam? Keen to project a perpetually rosy picture of the company to the investors, employees and analysts, Raju manipulated and fudged the account books so that it appeared a far bigger enterprise and more profitable, than it actually was. Here, M. Bhasin [12] remarked, "The Satyam reporting scam is clearly a case of abuse of accounting, in which the accounts were 'cooked-up' by creating fake invoices for the services not rendered, recognizing revenue on these fake receipts, falsifying the bank balances and interest on fixed deposits to show these fake invoices are converted into cash receipts and are earning interest, and so on". These types of fraudulent reporting accounting practices are both illegal and unethical. In its recent indictment of the former promoters and top managers of Satyam, the SEBI and other investigative agencies in India had finally provided minute and fascinating details about how India's largest corporate scam was committed. 
To the Board of Directors

Satyam Computer Services Lto.

From B. Ramalinga Raju

Chairman, Satyam Computer Services Ltd.

January 7,2009

Dear Board Members,

It is with deep regret, and tremendous burden that I am carrying on my conscience, that I would like to bring the following facts to your notice:

1. The Balance Sheet carries as of September 30, 2008

a. Inflated (non-existent) cash and bank balances of Rs.5,040 crore (as against Rs. 5361 crore reflected in the books)

b. An accrued interest of Rs. 376 crore which is non-existent

c. An understated liability of Rs. 1,230 crore on account of funds arranged by me

d. An over stated debtors position of Rs. 490 crore (as against Rs. 2651 reflected in the books:

2. For the September quarter (Q2) we reported a revenue of Rs. 2,700 crore and an operating margin of Rs. 649 crore $(24 \%$ of revenues) as against the actual revenues of 649 crore (24\% 0 revenues) as against the actual revenues of Rs, 2,112 crore and an actual operating margin of Rs. 61 Crore ( $3 \%$ of revenues). This

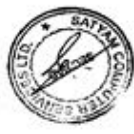

1. That neither myself, nor the Managing Director fincluding ou spouses) sold any shares in the last eight years - excepting for a small proportion declared and sold for philanthropic purposes.

2. That in the last two years a net amount of Rs. 1,230 crore was arranged to Satyam (not reflected in the books of Satyam) to keep the operations going by resorting to pledging all the promoter shares and raising funds from known sources by giving all kinds of assurances (Statement enclosed, only to the members of the board). Significant dividend payments, acquisitions, capital expenditure to provide for growth did not help matters. Every attempt was made to keep the wheel moving and to ensure prompt payment of salaries to the associates. The last straw was the selling of most of the pledged share by the lenders on account of margin triggers.

3. That neither me, nor the Managing Director took even one rupee/dollar from the company and have not benefitted in financial terms on account of the inflated results.

4. None of the board members, past or present, had any knowledge of the situation in which the company is placed. Even business leaders and senior executives in the company, such as, Ram Mynampati, Subu D, T.R. Anand, Keshab Panda, Virender Agarwal, A.S. Murthy, Hari T, SV Krishnan, Vijay Prasad, Manish Mehta, Murali V, Sriram Papani, Kiran Kavale, Joe Lagiola, Ravindra Penumetsa, Jayaraman and Prabhakar Gupta are unaware of the real situation as against the books of accounts. None of my or Managing Director's immediate or extended family members has any idea about these issues.

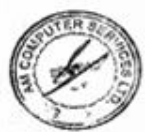

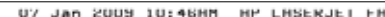

has resulted in artificial cash and bank balances going up by Rs. 588 crore in Q2 alone.

The gap in the Balance Sheet has arisen purely on account of inflated profits over a period of last several years (limited only to Satyam standalone, books of subsidiaries reflecting true performance). What started as a marginal gap between actual operating profit and the one reflected in the books of accounts continued to grow over the years. It has attained unmanageable proportions as the size of company operations grew significantly (annualized revenue run rate of Rs. 11,276 crore in the September quarter, 2008 and official reserves of Rs. 8,392 crore). The differential in the real profits and the one reflected in the books was further accentuated by the fact that the company had to carry additional resources and assets to justify higher level of operations -thereby significantly increasing the costs.

Every attempt made to eliminate the gap failed. As the promoters held a small percentage of equity, the concern was that poor performance would result in a take-over, thereby exposing the gap. It was like riding a tiger, not knowing how to get off without being eaten.

The aborted Maytas acquisition deal was the last attempt to fill the fictitious assets with real ones. Maytas' investors were convinced that this is a good divestment opportunity and a strategic fit. Once Satyam's problem was solved, it was hoped that Maytas' payments can be delayed. But that was not to be. What followed in the last several days is common knowledge.

I would like the Board to know:

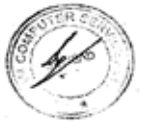

Having put these facts before you, I leave it to the wisdom of the boar to take the matters forward. However, I am also taking the liberty to recommend the following steps:

1. A Task Force has been formed in the last few days to address the situation arising out of the failed Maytas acquisition attempt. This consists of some of the most accomplished leaders of Satyam: Subu D, T.R. Anand, Keshab Panda and Virender Agarwal, representing business functions, and A.S. Murthy, Hari $T$ and Murali $V$ representing support functions. suggest that Ram Mynampati be made the Chairman of this Task Force to immediately address some of the operational matters on hand. Ram can also act as an interim CEO reporting to the board.

2. Merrill Lynch can be entrusted with the task of quickly exploring some Merger opportunities.

3. You may have a 'restatement of accounts' prepared by the auditors in light of the facts that I have placed before you.

I have promoted and have been associated with Satyam for well ove twenty years now. I have seen it grow from few people to 53,000 people, with 185 Fortune 500 companies as customers and operations in 66 countries. Satyam has established an excellent ieadership and competency base at all levels. I sincerely apologize to all Satyamites and stakeholders, who have made Satyam a special organization, for the current situation. I am confident they will stand by the company in this hour of crisis.

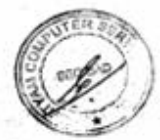

Figure 1 - Satyam's Founder, Chairman and CEO, Mr. Raju's Letter to his Board of Directors (pages 1-4) 


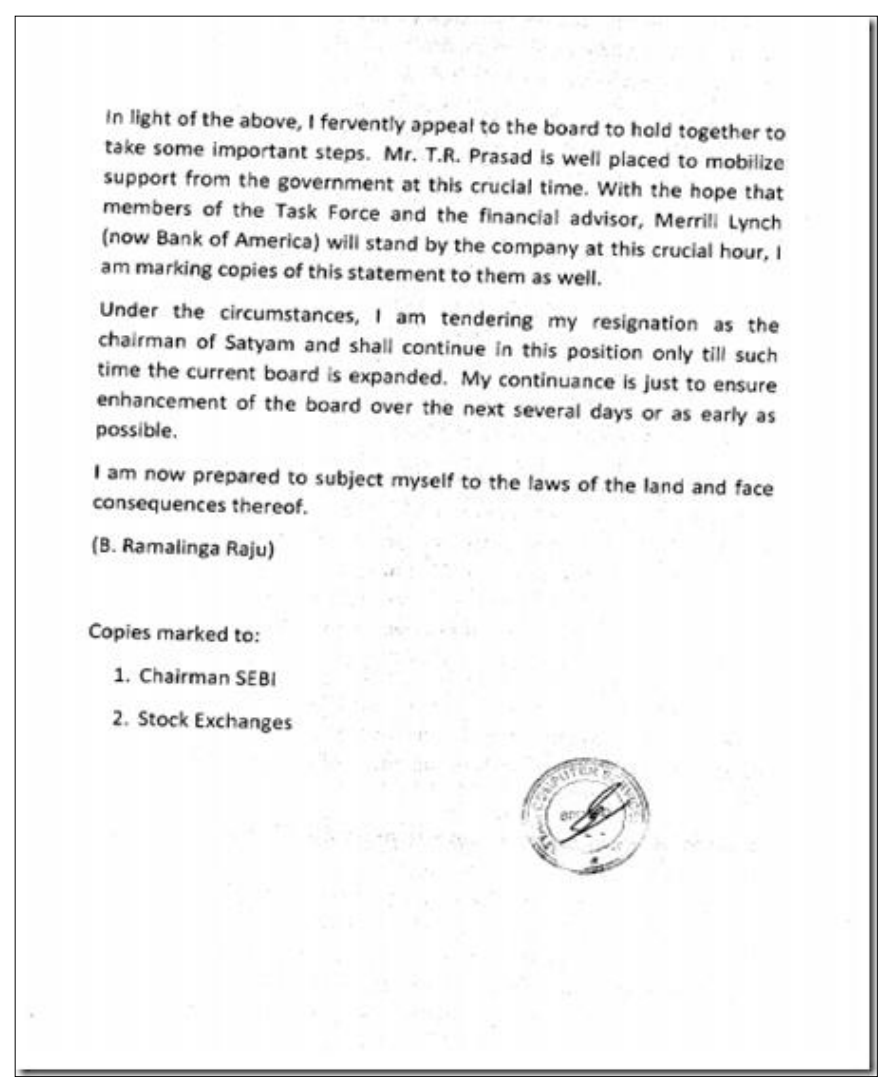

Figure 1 - Satyam's Founder, Chairman and CEO, Mr. Raju's Letter to his Board of Directors (page 5)

1. Web of Companies. "A web of 356 investment companies was used to allegedly divert funds from Satyam. Under Ramalinga Raju, Satyam floated 327 companies and published inflated financials," said M. Bhasin [15]. These front companies purchased 6,000 acres of land, taken loans of Rs. 1,230 crore from these companies, which were not even accounted in books. The CID investigation also revealed that Satyam had executed projects in the name of 7 non-existent companies. All these companies had several transactions in the form of inter-corporate investments, advances and loans within and among them. One such 'sister' company, with a paid-up capital of Rs. 5 lakh, had made an investment of Rs. 90.25 crore, and received unsecured loans of Rs. 600 crore.

2. Cooked-Up Books of Accounts. Raju maintained thorough details of the Satyam's cooked-up accounts and minutes of meetings since 2002 . He stored records of accounts for the latest year (2008-09) in a computer server called "My Home Hub". Details of accounts from 2002 till Jan. 7, 2009 (the day Mr. Raju came out with his dramatic 5-page confession) were stored in two separate Internet Protocol (IP) addresses. Keeping in view the media reports, M. Bhasin [17] is of firm opinion that "Satyam's top management simply cooked-up the company's books by overstating its revenues, profit margins, profits, ghost employees, etc. for every single quarter over a period of 5-years, from 2003 to 2008. In his letter, Raju admitted to inflating the cash and bank balances of the company by Rs. 5,040 crore. The company's total assets as on Sept. 30, 2008, stood at Rs. 8,795 crore. Of this, cash and bank balances stood at Rs. 5,313 crore (which was nearly 60\% of the total assets). This was overstated by Rs. 5,040 crore. The company basically had cash and bank balances of less than Rs. 300 crore".

The balance sheet of Satyam (as on 30 Sept., 2008) carried an inflated (non-existent) cash and bank balances of Rs. 5,040 crore, non-existent interest of Rs. 376 crore, and understated liability of Rs. 1,230 crore. In fact, the balance sheet carried an accrued interest of Rs. 376 crore, which was also non-existent. Table 2 depicts some parts of the Satyam's fabricated 'Balance Sheet and Income Statement' and shows the 'difference' between 'actual' and 'reported' finances. Keeping in view the modus-operandi successfully used by Satyam, M. Bhasin [14] remarked: "To show excess cash, several banks have to be 'fooled' (or asked to look the other way). To show huge fake 
revenues, everyone, from sales teams to MIS managers to accountants, had to be kept in the 'dark' (or conscripted into the conspiracy). To hide it all from investors and analysts, auditors had to be 'fooled' (or roped in as coconspirators). Some surely were. It is frightening that such large-scale fraudulent financial reporting scam, which is precisely the kind of thing our various 'watchdogs' are meant to prevent, can be perpetrated so casually by just a few people at the top!"

Table 2: Fabricated Parts of Balance Sheet and Income Statement of Satyam, Rs.

\begin{tabular}{|l|r|r|r|}
\hline \multicolumn{1}{|c|}{ Indicators } & Actual & Reported & Difference \\
\hline $\begin{array}{l}\text { Cash and Bank } \\
\text { Balances }\end{array}$ & 321 & 5,361 & 5,040 \\
\hline $\begin{array}{l}\text { Accrued Interest on } \\
\text { bank FDs }\end{array}$ & Nil & 376.5 & 376 \\
\hline $\begin{array}{l}\text { Understated } \\
\text { Liability }\end{array}$ & 1,230 & None & 1,230 \\
\hline Overstated Debtors & 2,161 & 2,651 & 490 \\
\hline Total & Nil & Nil & 7,136 \\
\hline $\begin{array}{l}\text { Revenues (Q2 FY } \\
\text { 2009) }\end{array}$ & 2,112 & 2,700 & 588 \\
\hline Operating Profits & 61 & 649 & 588 \\
\hline
\end{tabular}

\section{Falsification of Bank's Fixed Deposits Accounts.} As M. Bhasin [11] commented, "From the records of Satyam, as well as, the books held with the auditors, it was noted that two sets of letters of confirmation of balances of FDRs were available with the auditors. These two sets included confirmations actually sent by banks directly to the auditors (the genuine ones) in the prescribed format, and confirmations through forged letters purportedly sent from various bank branches, but forged". Thus, as on 30 Sept. 2008, while the actual FDs balances with various banks was just under Rs. 10 crore, fake FD receipts shown to the auditors totaled over Rs. 3,300 crore. Providing an explanation, M. Bhasin [17] described the motto and rationale for the process as, "Fake FDs had to be generated since fake business had to be shown to the stock markets, which meant the creation of fake customers and fake invoices from these businesses. Fake businesses generated fake revenues which, in turn, created the illusion of fake profit margins, and, finally, fake cash in the bank. Satyam apparently was very poor on its business fundamentals - with margins being low in many quarters, including nega- tive margins in some quarters". Indeed, falsification with regards to fixed deposit have been done since 2001-02 till 2007-08 and also for the quarter ended June 2008 and Sept. 2008.

4. Fake Invoices. M. Bhasin [16] stated, "Documents showed how the Satyam's standard billing systems were subverted to generate 'false' invoices to show 'inflated' sales, before its former boss, Raju, admitted to his role in the corporate scandal. The Satyam scandal involved this system structure being bypassed by the abuse of an emergency 'Excel Porting System', which allows invoices to be generated directly in IMS...by porting the data into the IMS". This system was subverted by the creation of a user ID called 'Super User' with 'the power to hide/unhide the invoices generated in IMS". The investigators had used cyber forensics to uncover how in-house computer systems were exploited to generate fake invoices. Regular Satyam bills were created by a computer application called 'Operational Real Time Management (OPTIMA)', which created and maintained information on all company projects. The 'Satyam Project Repository (SRP)' system then generated project IDs; there is also an 'Ontime' application for entering the hours worked by Satyam employees; and a 'Project Bill Management System (PBMS)' for billing. An 'Invoice Management System (IMS)' generated the final invoices. There were about 74,625 invoices generated in the IMS between April 2003 and Dec. 2008. The CBI found that "sales were inflated every quarter and the average inflation in sales was about 18\% [29].

5. Showing Fake Employees. To quote M. Bhasin [8], "One of the biggest sources of defalcation at Satyam was the inflation of the number of employees. Founder chairman of Satyam, Raju claimed that the company had 53,000 employees on its payroll. But according to investigators, the real number was around 43,000. The fictitious/ghost number of employees could be fabricated because payment to the remaining 13,000 employees was faked year-after-year: an operation that evidently involved the creation of bogus companies with a large number of employees". The money, in the form of salaries paid to ghost employees, came to around \$4 million a month, which was diverted through front companies and through accounts belonging to one of Mr. Raju's brothers and his mother to buy thousands of acres of land. Making up ghost employees might sound complicated, but investigators said it was 
not that difficult. "Employees are just code numbers in Satyam system; it can create any amount of them by creating bogus employee IDs with false address, time-sheets, opening fake salary accounts with banks, and collecting payments through an accomplice".

6. Lax Board of Directors. The Satyam Board was composed of "chairman-friendly" directors, who failed to question the management's strategy and use of leverage in recasting the company. Moreover, they were also extremely slow to act when it was already clear that the company was in financial distress. Here, M. Bhasin [6] observed, "The directors acted as mere rubber-stamps and the promoters were always present to influence the decision. The glue that held the board members together was Mr. Raju (Chairman). Each of the board members were there on his personal invitation and that made them ineffective. The Board ignored, or failed to act on, critical information related to financial wrong-doings before the company ultimately collapsed". It was only when Raju in the Dec. 2008 announced a \$1.6 billion bid for two Maytas companies (Maytas Infra and Maytas Properties) and while the share market reacted very strongly against the bid and prices plunged by $55 \%$ on concerns about Satyam's CG, that some of the IDs came into action by announcing their withdrawal from the Board, by than it was too late.

Satyam board's decision to invest 1.6 billion dollars to acquire a $100 \%$ stake in Maytas Properties and 51\% stake in Maytas Infrastructure (the two real estate firms promoted by Raju's sons) was in gross violation of the Companies Act 1956, under which no company is allowed, without shareholder's approval to acquire directly or indirectly any other corporate entity that is valued at over $60 \%$ of its paid-up capital. "Yet, Satyam's directors went along with the decision, raising only technical and procedural questions about SEBI's guidelines and the valuation of the Maytas companies. They did not even refer to the conflict of interest in buying companies in a completely unrelated business, floated by the chairman's relatives," remarked M. Bhasin [7]. Indeed, one of the independent directors even praised the merits of real-estate investment on Satyam's part.

\section{Unconvincing Role of Independent Directors.} With regard to the role of the 'independent' directors (IDs) at Satyam, we should understand: how 'independent' they actually were? It was seen that all the non-executive directors (NEDs) at Satyam have been allotted significant stock options at an unbelievable low strike price of Rs. 2 per share. Apart from this, all the NEDs have also earned handsome commissions during 2007-08, as reflected by Satyam's audited results. Naturally, a basic question arises here: "how can directors who had enjoyed such a huge largesse from the Company's promoters, had been beneficiaries of stock options given at an unbelievable strike price of Rs. 2 per share (against the ruling price of Rs. 500 per share in 2007-08), and who had received such high commissions could be expected to be 'independent'? According to M. Bhasin [5], "The idea of giving stock options to the IDs, was an intelligent ploy by Raju to successfully implement his plot at Satyam, with little resistance from the so-called independent directors, to whom, he was supposed to report to. It sounds ridiculous to listen to some of the IDs at the Press interviews (post-scandal) that they were not aware of what was going on at Satyam". "Satyam scam is one more proof that the mere compliance of SEBI's rule of the minimum number of independent directors does not guarantee ethical practices. Corporate history of the past decade has more than clearly shown that independent directors have not served their purpose," stated M. Bhasin [4].

8. Tunneling Strategy Used by Satyam. As part of their "tunneling" strategy, the Satyam promoters had substantially reduced their holdings in company from 25.6\% (in Mar. 2001) to $8.74 \%$ (in Mar. 2008). Furthermore, as the promoters held a very small percentage of equity (mere $2.18 \%$ ) on Dec. 2008, as shown in Table 3, the concern was that poor performance would result in a takeover bid, thereby exposing the gap. Here, M. Bhasin [9] reports, "The aborted Maytas acquisition deal was the final, desperate effort to cover up the accounting fraud by bringing in some real assets into the business. When that failed, Raju confessed the fraud. Given the stake the Raju's held in Matyas, pursuing the deal would not have been terribly difficult from the perspective of the Raju family".

As pointed out by S. Shirur [33], "Unlike Enron, which sank due to agency problem, Satyam was brought to its knee due to tunneling. The company with a huge cash pile, with promoters still controlling it with a small per cent of shares (less than 3\%), and trying to absorb a real-estate 
company in which they have a majority stake is a deadly combination pointing prima facie to tunneling". The reason why Raju claims that he did it was because every year he was fudging revenue figures, and since expenditure figures could not be fudged so easily, the gap between 'actual' profit and 'book' profit got widened every year. In order to close this gap, he had planned to buy Maytas Infrastructure and Maytas Properties. In this way, 'fictitious' profits could be absorbed through a 'self-dealing' process. M. Bhasin [3] concludes, "The auditors, bankers, and SEBI, the market watchdog, were all blamed for their role in the accounting fraud".

Table 3 - Promoter's Shareholding pattern in Satyam (in \%-age)

\begin{tabular}{|l|r|}
\hline \multicolumn{1}{|c|}{ Years } & Particulars \\
\hline 2001, March & 25.6 \\
\hline 2002, March & 22.26 \\
\hline 2003, March & 20.74 \\
\hline 2004, March & 17.35 \\
\hline 2005, March & 15.67 \\
\hline 2006, March & 14.02 \\
\hline 2007, March & 8.79 \\
\hline 2008, March & 8.74 \\
\hline 2008, December & 2.18 \\
\hline
\end{tabular}

9. Insider Trading Activities. Investigations into Satyam scam by the CID of the State Police and Central agencies have established that "the promoters indulged in nastiest kind of insider trading of the company's shares to raise money for building a large land bank". According to the SFIO Report findings, "promoters of Satyam and their family members during April 2000 to January 7, 2009 sold almost 3.9 crore number of shares thereby collecting in Rs. 3029.67 crore. During this course, the founder ex-chairman Ramalinga Raju sold 98 lakh shares collecting in Rs. 773.42 crores, whereas, his brother Rama Raju, sold 1.1 crore shares pocketing Rs. 894.32 crores". Finding these top managers guilty of unfair manipulation of stock prices and insider trading, SEBI has asked them to deposit their 'unlawful gains' of Rs. 1850 crore, with $12 \%$ interest, with the regulator within 45 days. They have also been barred from associating with the securities markets in any manner for the next 14 years.
10. Gaps in Satyam's Earnings and Cash Flows. After careful analysis, we can see there is no real difference in the trends in Satyam's net income and its cash flow from operations during 2004 and 2005, as shown in Figure 2.

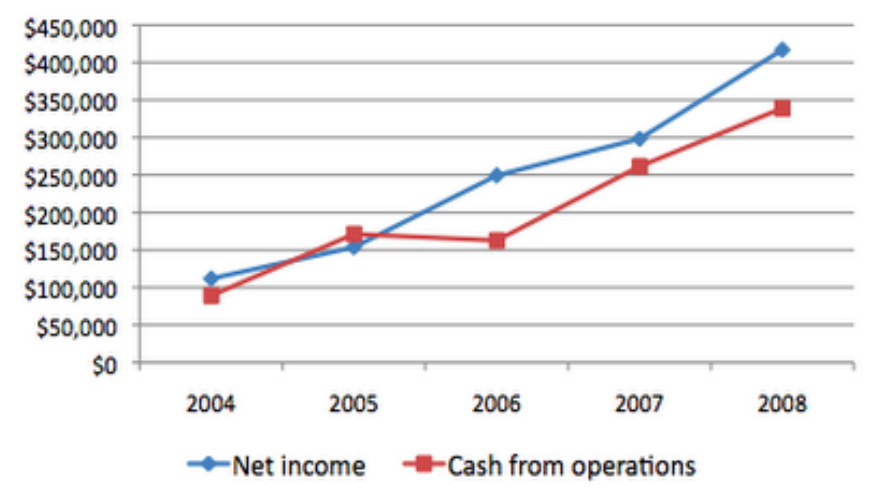

Figure 2 - Satyam's Earnings and Cash Flow, 2004-2008

Both net income and cash flow lines were almost overlapping each other. That is not because the earnings were genuine; it is because the cash flows were manipulated too. To do that, Raju's team had to forge several big amount accounts receivables, and simultaneously falsify about their cash collections. Thus, the fake cash flows had led to the bogus bank balances. However, wide gaps can be noticed in net income and cash flow from operation during 2006, 2007 and 2008, respectively. "During 2006 to 2008, cash flows were far less than net income due to accounting manipulations. Indeed, Satyam fraud was a stunningly and very cleverly articulated comprehensive fraud, likely to be far more extensive than what happened at Enron," said M. Bhasin [14].

11. Fake Audit and Dubious Role Played by Auditor's. Many experts cast partial blame for the accounting scandal on Satyam's auditor 'Price Waterhouse (PwC)' India, because the fraud went undetected for so many years. In fact, global auditing firm used Lovelock and Lewis (as their agent), who audited the Satyam's books of accounts from June 2000 until the discovery of the fraud in 2009. Several commentators criticized PwC harshly for failing to detect the fraud [36]. However, Raju's admission of having fudged the accounts for several years put the role of these statutory auditors on the dock.

The SFIO Report stated, "Statutory auditors instead of using an 'independent' testing mechanism used Satyam's investigative tools and 
thereby compromised on reporting standards". PwC did not check even 1\% of the invoices; neither did they pay enough attention to verification of sundry debtors, which (according to Raju's confession) was overstated by 23\% (SFIO report says it was overstated by almost $50 \%$ ). The Statutory auditors also failed in discharging their duty when it came to independently verifying cash and bank balances, both current account and fixed deposits. Hence, it was required that the PwC auditors independently check with the banks on the existence of Fixed Deposit's, but this was not done for as large as a sum of Rs. 5,040 crore. "The statutory auditors on whom the general public relied on for accurate information not only failed in their job but themselves played a part in perpetrating fraud by preparing a clean audit report for fudged, manipulated and cooked books," concluded Bhasin (2012).

It is shocking to know that "PwC outsourced the audit function to a local audit firm, Lovelock and Lewis, without the approval of Satyam". Unfortunately, the PwC audited the company for nearly 9 years and did not uncover the fraud, whereas Merrill Lynch discovered the fraud as part of its due diligence in merely 10 days. Missing these "red-flags" implied either that the auditors were grossly inept or in collusion with the company in committing the fraud. The CBI, which investigated the case, also charged the two auditors with complicity in the commission of the fraud by consciously overlooking the accounting irregularities. On April 22, 2014 "The Institute of Chartered Accountants of India (ICAI)" has imposed a life-time ban on four auditors involved in the Satyam CA fraud. A penalty of Rs. 5 lakh each was also levied on them. Strangely, Satyam's auditor, PwC, got away with a rap on its knuckles.

\section{Abnormal Audit Fees Paid to PwC India Agent.} A point has also been raised about the unjustified increase in audit fees. Table 4 shows that over a period of four years, 2004-05 to 2007-08, the audit fee increased by 5.7 times, whereas total income increased by 2.47 times during the same period. Here, Bhasin (2013) remarked, "Satyam also paid PwC twice what other firms would charge for the audit, which raised questions about whether PwC was complicit in the fraud". The Chairman of the AC's in the relevant years should have been interrogated by the investigators as to what justification did the $\mathrm{AC}$ have for recommending such a hike?
Table 4 - Satyam's Total Income and Audit Fees (Rs. in Millions)

\begin{tabular}{|l|r|r|r|r|}
\hline \multirow{2}{*}{ Indicators } & \multicolumn{4}{|c|}{ Years } \\
\cline { 2 - 5 } & $\begin{array}{c}2004- \\
2005\end{array}$ & $\begin{array}{c}2005- \\
2006\end{array}$ & $\begin{array}{c}2006- \\
2007\end{array}$ & $\begin{array}{c}2007- \\
2008\end{array}$ \\
\hline $\begin{array}{l}\text { Total } \\
\text { Income } \\
\text { (A) }\end{array}$ & 35,468 & $50,122.2$ & $64,100.8$ & $83,944.8$ \\
\hline $\begin{array}{l}\text { Audit Fees } \\
\text { (B) }\end{array}$ & 6.537 & 11.5 & 36.7 & 37.3 \\
\hline $\begin{array}{l}\text { \% of B to } \\
\text { A }\end{array}$ & 0.0184 & 0.0229 & 0.0573 & 0.0444 \\
\hline
\end{tabular}

Source: Annual Reports of Satyam, Percentage computed

The PwC received an annual fee of Rs. 37.3 million for financial year 2007-2008, which is almost twice, as what Satyam peers (i.e., TCS, Infosys, Wipro), on an average, pay their auditors. Bhasin (2015) stated, "This shows that the auditors were being lured by the monetary incentive to certify the cooked and manipulated financial statements. Events of such nature raised doubts about statutory auditors' discharging their duty independently". Consequently, on 24th Jan. 2009, two senior partners of PwC, Mr. S. Gopalakrishna and Mr. Srinivas Talluri were booked by Andhra Pradesh CID police on charges of fraud and criminal conspiracy. Also, the PwC had suspended the two partners, who signed on Satyam's balance sheet and are currently in prison.

13. Questionable Role of the Audit Committee. Recently, Bhasin (2016d) observed, "Surprisingly, the failure to detect the Satyam fraud is 'unimaginable' because it involved violating basic 'audit' procedures. Auditing 'cash' is so basic that people do not think twice about accepting the number, never thinking to ask questions about it". Still, a basic question arises: "Where was the Audit Committee (AC)?" As AC member, the directors have full-access to the auditors and right and responsibility to question the audit team. For instance, in the Satyam case after seeing an accumulated $\$ 1$ billion on the books, the AC should have raised questions about "what the company planned to do with the cash, or how much it was earning on the money, and so on". Moreover, Bhasin (2015) observed that "the timely action on the information supplied by a whistleblower to the chairman and members of the AC (an email dated December 18, 2008 by Jose Abraham), could serve as an SOS to the company, but they 
chose to keep silent and did not report the matter to the shareholders or the regulatory authorities".

Aftermath of Satyam Scandal. The news of the fraudulent financial reporting practices followed by Satyam sent jitters through the Indian stock market, and Sensex index fell more than 5\% and also Satyam shares fell by more than $70 \%$. Following the shocking disclosures by Mr. Raju (Chairman), the traders counter saw frantic selling on the bourses and nearly 143 million shares (or a quarter of the total 575 million shares) had changed hands and finally, the shares closed down $77.69 \%$ at Rs. 39.95 at the Bombay Stock Exchange (BSE), wiping out Rs.139.15 per share in a single day. After Wednesday's fall, the firm's market value has sunk to little more than $\$ 500$ million from around $\$ 7$ billion as recently as last June. The stock that hit its all-time high of Rs. 542 in 2008 crashed to an unimaginable Rs. 6.30 on the day Raju confessed on Jan. 9, 2009. Satyam's shares fell to 11.50 rupees on Jan. 10, 2009, their lowest level since March 1998, compared to a high of Rs. 544 in 2008. In the New York Stock Exchange, Satyam shares peaked in 2008 at US\$ 29.10; by March 2009 they were trading around US $\$ 1.80$. Thus, investors lost $\$ 2.82$ billion in Satyam.

Just a year later, the scam-hit Satyam was snapped up by Tech Mahindra for a mere Rs. 58 per share - a market cap of mere Rs. 5,600 crore. In the aftermath of Satyam, India's markets recovered and Satyam now lives on. India's stock market is currently trading near record highs, as it appears that a global economic recovery is taking place. Civil litigation and criminal charges continue against Satyam. As Shubhashish (2015) concluded, "On 13 April 2009, via a formal public auction process, a $46 \%$ stake in Satyam was purchased by Mahindra \& Mahindra owned company Tech Mahindra, as part of its diversification strategy. Effective July 2009, Satyam rebranded its services under the new Mahindra management as Mahindra Satyam. After a delay due to tax issues, Tech Mahindra announced its merger with Mahindra Satyam on 21 March 2012, after the board of two companies gave the approval. The companies are merged legally on 25 June 2013". As D. Winkler [36] states, "With the right changes, India can minimize the rate and size of accounting fraud in the Indian capital markets".
Investigation into the Satyam Case: Criminal \& Civil Charges. The Indian government immediately started an investigation, while at the same time limiting its direct participation. The government appointed a 'new' board of directors for Satyam to try to save the company: goal was to sell the company within 100 days [26]. On 7 Jan. 2009, the SEBI commenced investigations under the various SEBI regulations. The Ministry of Corporate Affairs (MCA) of the Central Government separately initiated a fraud investigation through its Serious Fraud Investigation Office (SFIO). In addition, the MCA filed a petition before the Company Law Board (CLB) to prevent the existing directors from acting on the Board and to appoint new directors. On 9 Jan. 2009, the CLB suspended the current directors of Satyam and allowed the Government to appoint up to 10 new "nominee" directors. Subsequently, the new, six-member Board had appointed a chief executive officer and external advisors, including the accounting firms KPMG and Deloitte to restate the accounts of Satyam.

"The Satyam fraudulent financial reporting scam/fraud has highlighted the multiplicity of regulators, courts and regulations involved in a serious offence by a listed-company in India. The lengthy and complicated investigations that were followed up after the revelation of the fraud has led to charges against several different groups of people involved with Satyam," says M. Bhasin [9]. Indian authorities arrested Mr. Raju, Mr. B. Ramu Raju (Raju's brother), its former managing director, Mr. Srinivas Vdlamani, the company's head of internal audit, and its CFO on criminal charges of fraud. Indian authorities also arrested and charged several of the company's auditors (PwC) with fraud. The Institute of Chartered Accountants of India (ICAI 2009) ruled that "the CFO and the auditor were guilty of professional misconduct".

All the accused involved in the Satyam fraud case were charged with cheating, criminal conspiracy, forgery, breach of trust, inflating invoices and profits, faking accounts and violating number of income tax laws. The CBI had filed three chargesheets in the case, which were later clubbed into one massive charge-sheet running over 55,000 pages. Over 3000 documents and 250 witnesses were parsed over the past 6 years. A special CBI court on April 9, 2015 finally, sentenced Mr. B. Ramalinga Raju, his two brothers and seven others to seven years in prison in the Satyam fraud 
case. The court also imposed a fine of Rs. 5 crore on Ramalinga Raju, the Satyam founder and former chairman, and his brother B. Rama Raju, and Rs. 20-25 lakh each on the remaining accused [25]. The 10 people found guilty in the case are: B. Ramalinga Raju; his brother and Satyam's former managing director B. Rama Raju; former chief financial officer Vadlamani Srinivas; former PwC auditors Subramani Gopalakrishnan and T. Srinivas; Raju's another brother, B Suryanarayana Raju; former employees (G. Ramakrishna, D. Venkatpathi Raju and Ch. Srisailam); and Satyam's former internal chief auditor V.S. Prabhakar Gupta.

\section{Conclusion and Recommendation}

Satyam, a global IT-company based in India, has just been added to a notorious list of companies involved in fraudulent financial reporting practices. Satyam's CEO and Chairman, Mr. B. Ramalingam Raju, took the final responsibility for all the accounting improprieties. "This leads one to ask a simple question: How does this keep on happening for five years, without any suspicions?" asked M. Bhasin [17]. So, while Raju ran his fraud, the auditor slept, the analysts slept, and so did the media. To be fair, finally, the media and a whistle-blower did an excellent job of exposing Raju and his many other "shenanigans" after he had confessed. In his letter (of Jan. 7, 2009) addressed to board of directors of Satyam, Raju showed the markers of this fraud 'pathology'. Now, more than six years later, the final decision in the Satyam scam has been made and all accused charge-sheeted in the case have been awarded punishment by the Court.

The Satyam fraudulent financial reporting scam is a glaring example of 'abuse' of accounting, in which the account books were cooked up. Recently, M. Bhasin [16] lucidly pointed out that "the culture at Satyam (especially dominated by the board) symbolized an unethical culture". This scam brought to light the role of CG in shaping the protocols related to the working of Audit Committee and duties of Board members. Now, it is amply clear that the Satyam scam was plotted at the top and driven by Ramalinga Raju and his brother. They were the key players in the plot to falsify the accounts and hide the bottom-line truth from everyone. It is also clear that all the culprits - from Raju down to the finance guys did everything possible to give SEBI and other investigative agencies a run-around and delay the verdict. This is what explains, why it took more than five-and-a-half years to close an openand-shut-case. It took nearly 2 years, involvement of multitude of investigation agencies, and over 200 experts to assess the total damage of the scam perpetrated by Raju. Now, the final figure is a shade under Rs. 8,000 crore. A special CBI Court in Hyderabad on April 9, 2015 finally, sentenced all the 10 people involved in the multicrore accounting scam found guilty of cheating, forgery, destruction of evidence and criminal breach of trust, almost the six-year-old case has reached its logical conclusion. Undoubtedly, the Indian government took quick actions to protect the interest of the investors, safeguard the credibility of India, and the nation's image across the world.

According to A. Chopra [20], President of ICAI, "The Satyam scam was not an accounting or auditing failure, but one of CG. This apex body found the two PwC auditors 'prima-facie' guilty of professional misconduct". The CBI also charged the two auditors with complicity in the commission of the fraud by consciously overlooking the accounting irregularities. As A. Krishnan [26] pointed out, "Yet both Satyam's internal as well as statutory auditors did not bring it to anyone's notice. Well, the internal auditor hauled up by SEBI has frankly admitted that he did notice differences in the amounts billed to big clients, such as Citigroup and Agilent, when he scoured Satyam's computerized accounts. But when he flagged this with Satyam's finance team, he was fobbed off with the assurance that the accounts would be 'reconciled'. Later, he was 'assured' that the problem had been fixed". We strongly recommend that "Fraudulent financial reporting practices should be considered as a serious crime, and as such, accounting bodies, law courts and other regulatory authorities in India need to adopt very strict punitive measures to stop such unethical practices". According to the Association of Certified Fraud Examiner's Report to the Nations [2], "Their survey estimated that the typical organization loses $5 \%$ of revenues in a given year as a result of fraud... India ranks second in terms of victim organizations reporting fraud cases". Finally, the responsibility of preventing, detecting and investigating corporate and financial frauds rests squarely on Board of Directors and this requires them to adopt preventive steps. Also, the Board of Directors and top-management should 
jointly agree and define their anti-fraud strategy, establish appropriate fraud mitigation steps, and train their employees to combat financial and corporate frauds. Shockingly, no full-proof system could be developed, so far, by the multiple local and international regulatory bodies across the globe. Hence, the global corporate stake- holders' "dubs the rising cases and magnitude of frauds as an inevitable cost of doing business". Although, corporate world cannot be $100 \%$ secure against unknown threats, a certain level of preparedness can go a long way in countering fraud risks.

\section{References}

1. Agrawal, S. \& Sharma, R. (2009, January 10). Beat this: Satyam won awards for corporate governance. VCCircle Network. Retrieved from http://www.vccircle.com/news/technology/2009/01/09/beat-satyam-won-awards-corpgovernance-internal-audit

2. ACFE. (2016). Report to the Nations on Occupational Fraud and Abuse: 2012 Global Fraud Study. Retrieved from http://www.acfe.com/uploadedFiles/ACFE_Website/Content/rttn/2012-report-tonations.pdf

3. Bhasin, M. L. (2007). Forensic Accounting: A New Paradigm for Niche Consulting. The Chartered Accountant, Jan., 1000-1010. Retrieved from http://resource.cdn.icai.org/97231000-1010.pdf

4. Bhasin, M. L. (2008). Corporate Governance and Role of the Forensic Accountant. The Chartered Secretary, 38(10), 1361-1368.

5. Bhasin, M. L. (2010). Corporate Governance Disclosure Practices: The Portrait of a Developing Country. International Journal of Business and Management, 5(4), 150-167. doi 10.5539/ijbm.v5n4p150

6. Bhasin, M. L. (2011). Corporate Governance Disclosure Practices: The Portrait of a Developing Country. International Review of Business Research Papers, 7(1), 393-419.

7. Bhasin, M. L. (2012). Corporate Accounting Frauds: A Case Study of Satyam Computers Limited. International Journal of Contemporary Business Studies, 3(10), 16-42.

8. Bhasin, M. L. (2012). Audit Committee Mechanism to Improve Corporate Governance: Evidence from a Developing Country. Modern Economy, 3(11), 856-872. doi 10.4236/me.2012.37109

9. Bhasin, M. L. (2013). Corporate Accounting Scandal at Satyam: A Case Study of India's Enron. European Journal of Business and Social Sciences, 1(12), 25-47.

10. Bhasin, M. L. (2013). Corporate Accounting Fraud: A Case Study of Satyam Computer Limited. Open Journal of Accounting, 2(2), 26-38. doi 10.4236/ojacct.2013.22006

11. Bhasin, M. L. (2013). Corporate Governance and Role of the Forensic Accountant: An Exploratory Study of an Asian Country. Amity Business Review, 14(1), 48-71.

12. Bhasin, M. L. (2015). Forensic Accounting: Perspectives and Prospects. Pakistan Accountant, Oct.Dec., 44-48.

13. Bhasin, M. L. (2015). Menace of Frauds in Banking Industry: Experience of a Developing Country. Australian Journal of Business and Management Research, 4(12), 21-33. Retrieved from http://www.ajbmr.com/files/download/adee1c0429515a4

14. Bhasin, M. L. (2015). Creative Accounting Practices in the Indian Corporate Sector: An Empirical Study. International Journal of Management Science and Business Research, 4(10), 35-52. Retrieved from http://thejournalofbusiness.org/index.php/site/article/view/948/610

15. Bhasin, M. L. (2016). Debacle of Satyam Computers Limited: A Case Study of India's Enron. Wulfenia Journal, 23(3), 124-162.

16. Bhasin, M. L. (2016). Survey of Creative Accounting Practices: An Empirical Study. Wulfenia Journal, 23(1), 143-162.

17. Bhasin, M. L. (2016). Unethical Creative Accounting Culture at Satyam Computers Limited: A Case Study of India's Enron. International Journal of Business and Social Research, 6(7), 24-48.

18. Bhasin, M. L. (2016). Strengthening Corporate Governance through an Audit Committee: An Empirical Study. Wulfenia Journal, 23(2), 2-27.

19. Bhasin, M. L. (2016). Contribution of Forensic Accounting to Corporate Governance: An Exploratory 
Study of an Asian Country. International Business Management, 10(4), 479-492. Retrieved from http://www.isihome.ir/freearticle/ISIHome.ir-24088.pdf

20. Chopra, A. (2011, January 25). Satyam fraud, not an accounting failure: ICAI. Business Standard. Retrieved from http://www.business-standard.com/article/economy-policy/satyam-fraud-not-anaccounting-failure-icai-111012500023_1.html

21. Gupta, P. K. \& Gupta, S. (2015). Corporate frauds in India: Perceptions and emerging issues. Journal of Financial Crime, 22(1), 79-103. doi 10.1108/JFC-07-2013-0045

22. ICAI finds ex Satyam CFO, Price Waterhouse auditors guilty. (2009, September 28). The Hindu. Retrieved from http://www.thehindu.com/business/Industry/icai-finds-exsatyam-cfo-pricewaterhouse-auditors-guilty/article26189.ece

23. ICAI. (2014, April 22). The Institute of Chartered Accountants of India has imposed a life-time ban on four auditors. Retrieved from http://m.scirp.org/papers/70827

24. India's Satyam Scandal: A Blessing in Disguise? (2015, December 20). China India Institute. Retrieved from http://www.chinaindiainstitute.com/indias-satyam-scandal-a-blessing-in-disguise2

25. Kaul, V. (2015, April 10). Satyam scam: Ramalinga Raju, the man who knew too much, gets 7 years in jail. F. Business. Retrieved from http://www.firstpost.com/business/satyam-scam-ramalingaraju-the-man-who-knew-too-much-gets-7-years-in-jail-2190739.html

26. Krishnan, A. (2014, July 18). Finally, the truth about Satyam. The Hindu Business Line. Retrieved from http://www.thehindubusinessline.com/opinion/columns/aarati-krishnan/finally-thetruth-about-satyam/article6225718.ece

27. Miller, G. S. (2006). The press as a watchdog for accounting fraud. Journal of Accounting Research. 44(5), 1001-1033. doi 10.1111/j.1475-679X.2006.00224.X

28. Pai, K. \& Tolleson, T.D. (2015). India's Satyam Scandal: Evidence the too Large to Indict Mindset of Accounting Regulators is a Global Phenomenon. Review of Business and Finance Studies, 6(2), 3543. Retrieved from https://bibliotecausatpdqt.files.wordpress.com/2014/12/indias-satyamscandal_evidence-the-too-large-to-indict-mindset-of-accounting-regulators-is-a-globalphenomenon.pdf

29. Ramana, K. V. (2009, April 15). 7,561 fake invoices = Rs. 5,117 crore sales. DNA. Retrieved from http://www.dnaindia.com/money/report-7561-fake-bills-rs-5117-cr-sales-1247889

30. Ramachadran, S. (2009). Raju brings down Satyam, shakes India. Retrieved from http://www.atimes.com/atimes/South_Asia/KA09Df01.html

31. Reurink, A. (2016). Financial Fraud: A Literature Review. MPIfG Discussion Paper, 16/5. Retrieved from https://www.econstor.eu/bitstream/10419/141282/1/859161242.pdf

32. SFIO. (2009). SFIO Report published in the Pioneer. New Delhi, India: n. d.

33. Shirur, S. (2011). Tunneling vs. Agency Effect: A Case Study of Enron and Satyam. Vikalpa, 36(3), 920. Retrieved from http://www.vikalpa.com/pdf/articles/2011/Pages-from-Vikalpa36-3-920.pdf

34. Shubhashish. (2015, April 9). All that you need to know about the Satyam Scam. DNA. Retrieved from http://www.dnaindia.com/money/report-all-that-you-need-to-know-about-the-satyamscam-2067138

35. Brown, V., Daugherty, B., \& Persellin, J. (2014). Satyam Fraud: A Case Study of India's Enron. Issues in Accounting Education, 29(3), 419-442. doi 10.2308/iace-50735

36. Winkler, D. (2010, March 30). India's Satyam Accounting Scandal. Retrieved from: http://blogs.law.uiowa.edu/ebook/content/uicifd-briefing-paper-no-8-indias-satyamaccounting-scandal

37. Knowledge@Wharton (2009, January 09). Scandal at Satyam: Truth, Lies and Corporate Governance. Retrieved from http://knowledge.wharton.upenn.edu/article/scandal-at-satyam-truthlies-and-corporate-governance

(C) M. L. Bhasin 


\title{
Мошенническая практика отчетности Satyam
}

\author{
Madan Lal Bhasin \\ University Utara Malaysia \\ School of Accountancy, College of Business, Professor, Kedah Darul Aman, Malaysia
}

\begin{abstract}
Аннотация. Мошеннические практика финансовой отчетности может иметь серьезные последствия для организаций и всех заинтересованных сторон, а также, для общественного доверия в столице и безопасности рынков. На самом деле, исчерпывающая, точная и надежная финансовая отчетность является основой, на которой базируются наши рынки. Движимый желанием создать радужную картину компании Satyam для инвесторов, сотрудников и аналитиков, г-н Raju (генеральный директор и председатель) подделал отчетность таким образом, чтобы предприятие казалась более крупным, чем на самом деле, с более высокой прибылью и быстрыми темпами роста. Мошенничество Satyam разрушило мечты разных категорий инвесторов, шокировало правительство и регулирующие органы и привело к расследованию практики бухгалтерского учета, аудита и норм корпоративного управления в Индии. Это предварительное исследование проведено на основе вторичных источников информации. Дано объяснение различным вопросам, касающимся жульничества Satyam. После тщательного расследования со стороны CBI и SEBI, была представлена методология, с помощью которой было спроектировано мошенничество Satyam. И, наконец, мы рекомендуем: «Мошеннические практики отчетности следует рассматривать как серьезное преступление, и бухгалтерские органы, суды и другие регулирующие органы Индии должны принимать очень строгие карательные меры для предотвращения подобных неэтичных практик.
\end{abstract}

Ключевые слова: мошенническая практика финансовой отчетности; компьютер Satyam; modus-operandi; финансовая отчетность; корпоративное управление; аудиторы; судебно-бухгалтерская экспертиза; корпоративная культура и этика; SEBI; SFIO; CID; Индия.

УДК 364.22:631

DOI: http://dx.doi.org/10.22178/pos.15-4

JEL Classification: I3, Q12, R2

(C) M. L. Bhasin

Статья получена 01.10.2016, принята 12.10.2016, опубликована online 17.10.2016 